\title{
DIE ONTSTAAN EN ONTWIKKELING VAN DIE VLOOT 1912-1982
}

\author{
O/It (SAV) J.D. Bredenkamp*
}

Not only does the South African Navy have a proud history, but it is constantly occupied with the building of a highly efficient, modern naval power. The origin and development of the South African Navy since 1912 to the present day is discussed and special attention is given to the facts and occurrences that merit emphasis from either a historical or military point of view.

\section{Inleiding}

Gedurende die negentiende eeu het die handel tussen Europa en die Ooste grootskaals vermeerder en het die hawens van Kaapstad en later ook Durban, Oos Londen en Port Elizabeth gebloei. Maar die Suid-Afrikaners self, ongeag die feit dat hulle afstammelinge was van groot seevarende lande soos Holland en Engeland, het min belangstelling getoon in maritieme sake. Selfs die vissery- en walvishandel is slegs op ' $n$ klein skaal beoefen.

Dit is daarom geen verrassing dat die eerste vlooteenhede van Suid-Afrika landgebonde was nie. Die eerste van hierdie eenhede was die Port Elizabeth Naval Volunteer Brigade, gestig in Julie 1861 onder bevel van Kaptein Chapman. Hy was voorheen in bevel van ' $n$ Vlootbrigade in Indië. Dit was gerugte van 'n oorlog teen Rusland wat 'n tweede vlooteenheid tot stand gebring het; die sogenaamde Natal Naval Volunteers in 1885, en het bestaan uit 100-150 man te Durban. In 1905 is dit gevolg deur die Cape Colonial Division of RNVR (Royal Naval Volunteer Reserve).

Ten tye van die totstandkoming van die Unie van Suid-Afrika (1910) het die Minister van Verdediging, genl J.C. Smuts, planne begin beraam om 'n verdedigingstelsel vir die Unie te ontwerp en om binne die raamwerk van hierdie stelsel rekening te hou met imperiale land-en see-verdedigingsvraagstukke. Ondermeer het hy besluit om die bestaande RNVR skema, soos dit in Natal en die Kaapkolonie wortel geskiet het, onder oë te neem en te hersien.

In die koloniale wetgewing van Natal en die Kaapkolonie is voorsiening gemaak vir 'n jaarlikse bydrae van R170 000 aan die Britse Vloot. Na 31 Mei 1910 het hierdie uit die inkomste van

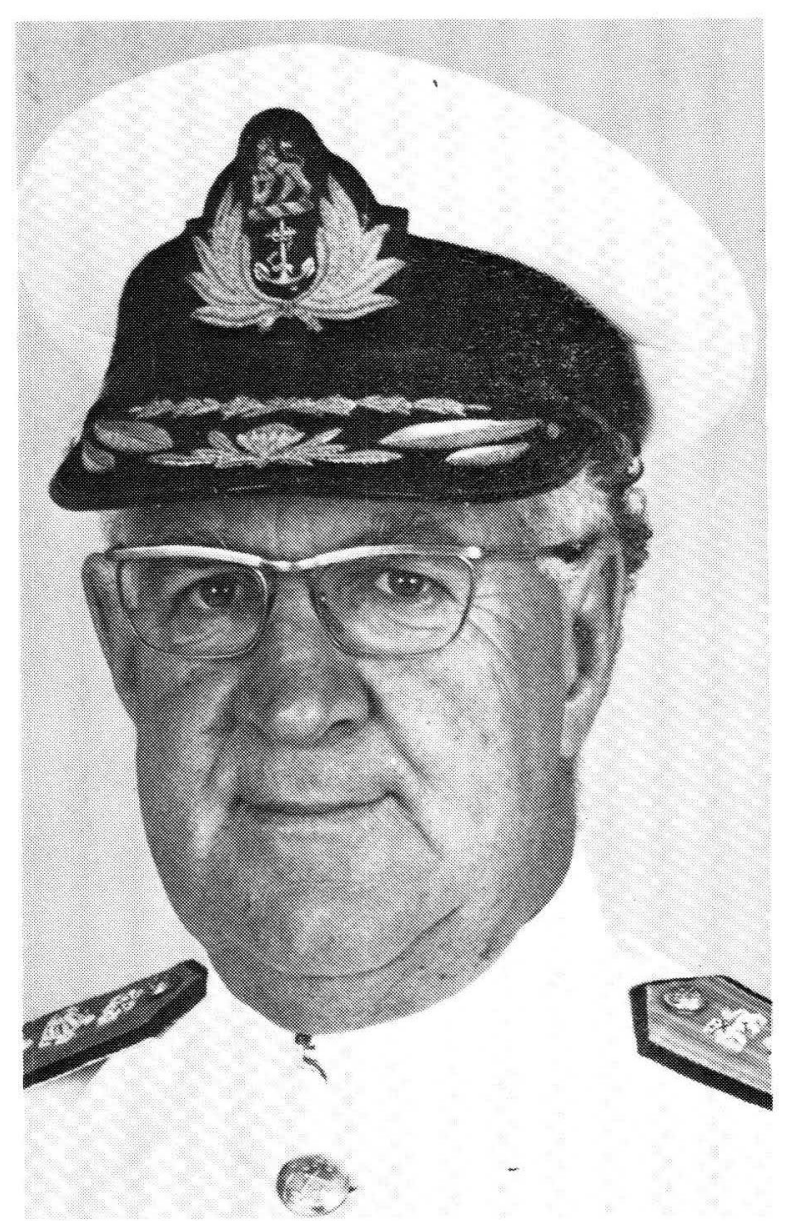

V-adm R.A. Edwards, SSAS, SM Hoof van die Vloot sedert 1 Februarie 1980

die Unie gekom en het altans ten opsigte van die finansiële jaar 1910-1911, die Unieparlement sy goedkeuring hieraan geheg.

Die Britse wetgewers het die daarstelling van afsonderlike vlootmagte van die dominiums beoog wat in 'n besonder groot mate deur die onderskeie dominiums geadministreer en gekontroller sou word. 
Genl Smuts het, aldus sy ondersekretaris, die volgende beoog: "The creation of a force to be given to the Admiralty to use, administer and control both in peace and war, while the Union Executive Govt. and Parliament should retain full constitutional control."

Met die publisering van die Verdedigingsregulasies op 23 Desember 1912 het 'n nuwe era gevolg in die geskiedenis van die Weermag. Hierdie regulasies het voorsiening gemaak vir die samesmelting van die Natal Naval Volunteer en Cape Colonial Division of RNVR op 1 Julie 1913 en het bekend gestaan as Royal Naval Volunteer Reserve (South Africa Division).

\section{Die Eerste Wêreldoorlog}

In Augustus 1914 breek die Eerste wêreldoorlog uit en die RNVR SA Division bestaande uit 12 offisiere en 267 onderoffisiere en manskappe word gemobiliseer. ' $n$ Groot hoeveelheid van die Suid-Afrikaners het feitlik onmiddellik op Britse kruisers gedien, wat op lêplek was, gereed om af te reken met Von Spee se vlooteskader (bekend as "Von Spee's China squadron") want sy eskader was 'n groot bedreiging in die vroeë stadiums van die oorlog. Ander het weer die kusbatterye beman en in Oos-Afrika, Gallipoli en op skepe van die Britse vloot gedurende die slag van Jutland gedien.

Met genl Louis Botha se terugkeer van die Vredeskonferensie was hy vasberade om 'n vloot eie aan Suid-Afrika op die been te bring. Dit wil sê in plaas van dat Suid-Afrika $£ 85000$ 'n jaar aan die Britse Vloot betaal sou daar nou gepoog word om eie skepe te bekom. Daar is op die Imperiale Vergadering van 1921 besluit om 'n vloot as deel van die Unieverdedigingsmag te stig.

In 1921 het die Suid-Afrikaanse regering die uitgediende Britse kruiser HMS Thomas gekoop en - as die Generaal Botha - het dié skip vir baie jare as opleidingskip vir offisiere in die handelsvloot gedien. Baie van hierdie offisiere sou egter mettertyd hul weg na die Suid-Afrikaanse Vloot vind.

Op hierdie wyse dan het die Suid-Afrikaanse Seediens op 1 April 1922 tot stand gekom wat in Proklamasie No 17/1923 met ingang van $1 \mathrm{Fe}-$ bruarie 1923 as 'n eenheid van die Staande Mag van die toenmalige Unieverdedigingsmag beskou is.
Die eerste vlootvaartuie was die HM SAS Sonneblom, HM SAS Immortelle (klein mynveërireilers) en HM SAS Protea ('n gewese Britse mynveër), drie skepe van beskeie tonnemaat; vaartuie aan boord waarvan 'n groot aantal van ons landsgenote vir die eerste keer die see bevaar het of ' $n$ ou aangename kennismaking hernu het.

Kommandeur N.H. Rankin was in bevel van die jong organisasie wat as gevolg van die ekonomiese depressie, die hieruit-voortvloeiende besparing en ander faktore in 1933 op 'n sterkte van nege offisiere en sewe-en-veertig manskappe te staan gekom het. In 1934 is die HM SAS Immortelle en die HM SAS Sonneblom aan die Britse vloot oorgedra, terwyl die Protea op 30 April 1933 uit die diens gestel is. Die Suid-Afrikaanse Seediens het as 'n seevarende mag verdwyn. Gelukkig het die uitgedunde oorblywende organisasie bly voortbestaan. Ten tye van die Unie se toetrede tot die Tweede Wêreldoorlog (6 Sept 1939) was daar nog twee offisiere, luitenant-kommandeurs J. Dalgleish en F.J. Dean, en drie manskappe, H.S. Creswell, J.C.M. Germishuys en W.J.C. Magson oor. Die reeds meermaal vermelde RNVR (SA Division) het in teenstelling hiermee, ' $n$ bloeitydperk beleef.

\section{Die Tweede Wêreldoorlog}

Dit is vandag algemeen bekend dat Suid-Afrika, net soos 'n groot aantal ander lande ten tye van die uitbreek van die Tweede Wêreldonrlog militêr onvoorbereid was. Ten opsigte van die vlootorganisasie was daar ' $n$ kern aanwesig, maar dit was 'n seediens sonder skepe. Gelukkig was daar egter 'n klein groepie goed-opgeleide manne wat vir vlootdiens aangewend kon word. Hulle was naamlik lede of gewese lede van die RNVR (SA), of persone wat opleiding aan boord van Generaal Botha ontvang het. Die RNVR het naamlik deur die jare - en steeds onder direkte beheer van die Britse Vloot, gefloreer. Net soos die res van die Unieverdedigingsmag is die Suid-Afrikaanse Seediens (South African Naval Service - SANS) nie gemobiliseer nie, maar vrywilligers kon by die Britse Vloot aansluit. Die RNVR (SA) is as deel van die Britse Vloot gemobiliseer, en 1760 offisiere en manskappe sou in die Britse Vloot diens doen.

Genl Smuts het, nadat Suid-Afrika op 6 September 1939 teen Duitsland oorlog verklaar het, skout-adm G.W. Hallifax, 'n afgetrede Britse offi- 


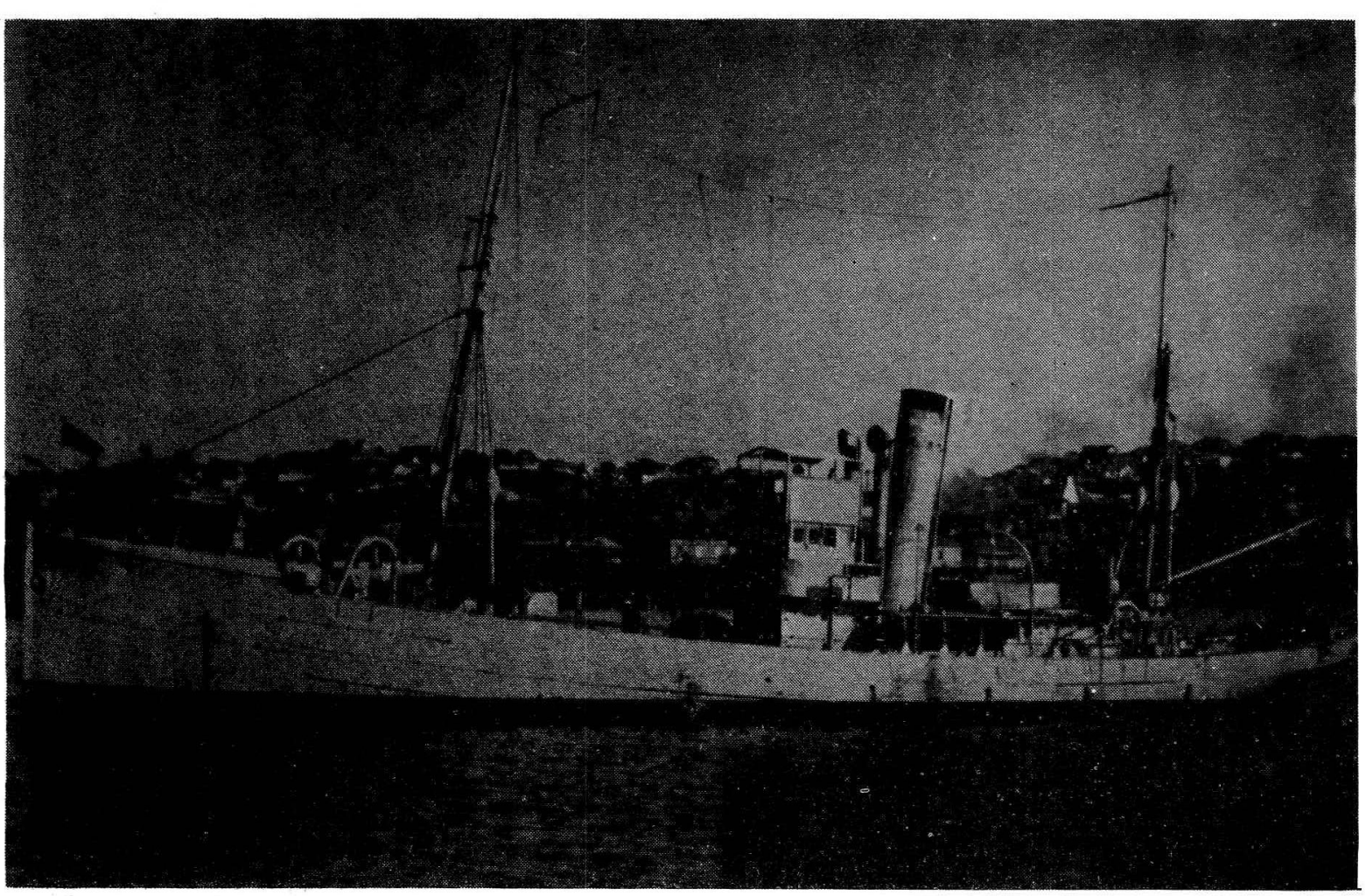

Dle Immortelle, een van die eerste skepe van die SuidAfrikaanse Vloot

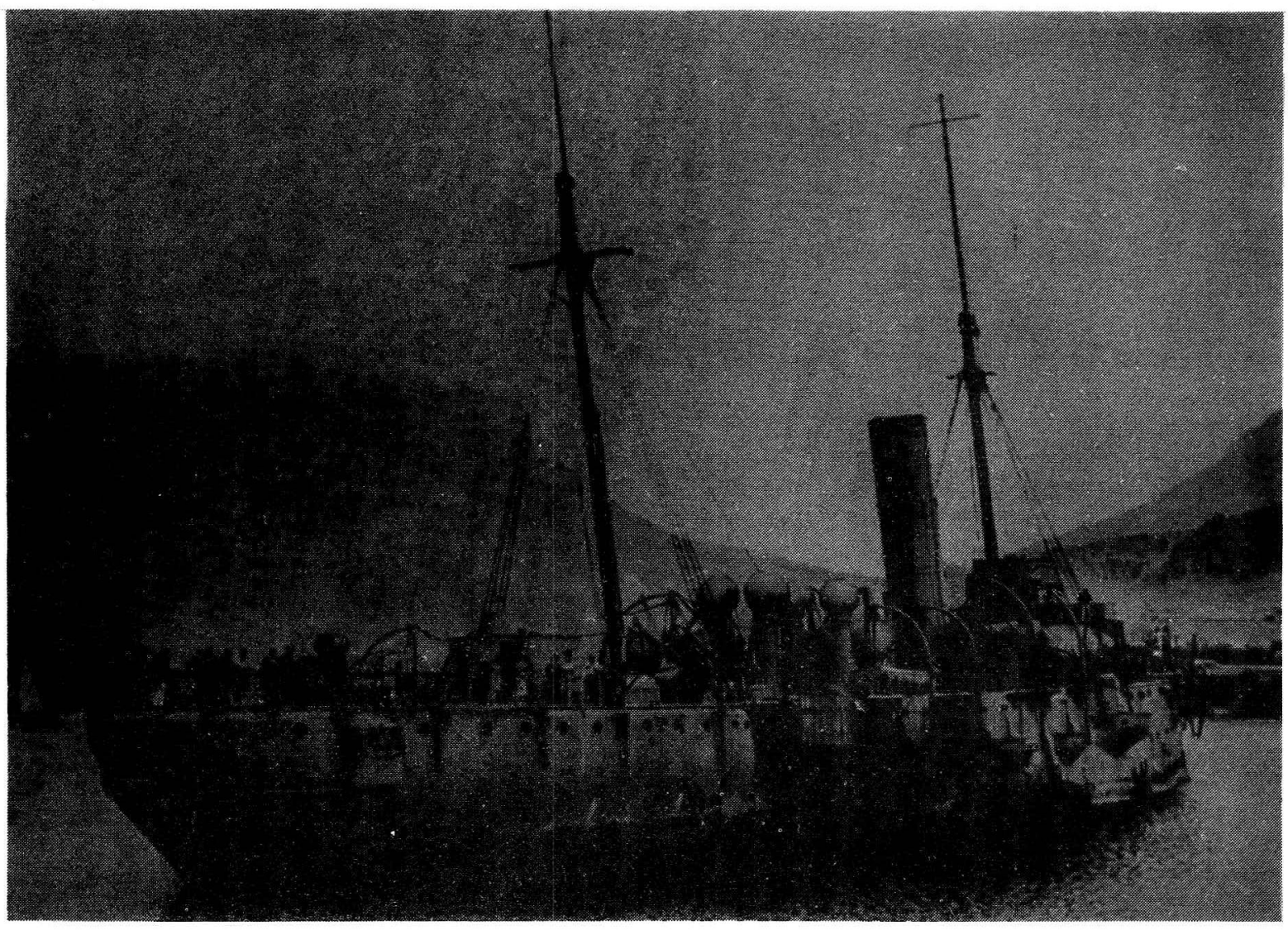

Nog 'n voorbeeld van een van die Suid-Afrikaanse Vloot se eerste skepe, die opleidingskip Louis Botha 
sier wat toe in Suid-Afrika woonagtig was, gevra om 'n vlootmag in Suid-Afrika op die been te bring. In Maart 1939 is reeds 'n opname gemaak van 51 treilers en walvisjagters wat, sou die situasie dit noodsaak, oorgeneem en vinnig in vlootvaartuie omskep kon word. Dit is dan toe ook gedoen, en binne ' $n$ kort tyd is sommige van die skepe in mynveërs en duikbootjagters omskep. In November 1939 is kennis gegee van 'n besluit om 'n Verdedigingsmag ter See (Seeward Defence Force - SDF) as die eerste permanente vlooteenheid in Suid-Afrika in te stel. Die SDF is op 15 Januarie 1940 formeel gekonstitueer. Die lede van die SANS is outomaties daarna oorgeplaas, maar die RNVR (SA) het onafhanklik bly voortfunksioneer. Die SDF het aanvanklik 47 offisiere en 381 manskappe gehad met basisse te Durban, Kaapstad, Simonstad, Port Elizabeth en Oos-Londen. Elke basis het naas 'n aantal mynveërs en duikbootjagters ook geriewe vir die skepe en 'n seinstasie gehad, asook 'n visenteerdiens. Laasgenoemde moes alle skepe wat Suid-Afrikaanse hawens wou binnegaan, deursoek.

Op 16 Mei 1940 is die eerste vyandelike seemyn om Suid-Afrika se kus opgespoor. Vir die volgende ses maande was Suid-Afrikaanse mynveërs druk besig om 'n Duitse mynveld, wat op 10 Mei 1940 deur die kaperskip Atlantis gelê is op te ruim. Langs ons kus was die mynveërs onder meer by Kaap Agulhas bedrywig om die skeepvaartroete te beveilig, terwyl mynvelde by Kaap Columbine, Dangerpoint en in die noordwestelike toegangsgebied tot Tafelbaai ook opgeruim is.

Slegs twee Geallieerde vragskepe sou binne 1000 seemyl $(1825 \mathrm{~km})$ vanaf Suid-Afrikaanse kuste deur vyandelike seemyne gekelder word, terwyl slegs twee ander, asook 'n oorlogskip, deur seemyne beskadig is - iets wat beslis 'n aanduiding is van die doeltreffendheid van die Suid-Afrikaanse mynveërs en hulle bemannings.

Vanaf September 1940 tot Januarie 1941 en weer vanaf Junie 1941 tot Maart 1942 is daar 'n groot hoeveelheid tyd verspil op nuttelose amfibiese landingsoefeninge vir geval Portugal sou oorgaan na die Spilmoondhede, en Suid-Afrika verplig sou wees om Mosambiek binne te val. Hierdie oefeninge is gelukkig later gestaak.

Stadige vordering is gemaak met die maritiemeverdeding van die Unie en vroeg in 1941 is Walvisbaai uitgerus met kusartillerie. Dit was tydens 'n inspeksiebesoek aan Walvisbaai in
Maart 1941, dat admiraal Halifax te sterwe gekom het in 'n vliegongeluk. Hy word opgevolg deur Kaptein Dalgleish as Direkteur van SDF.

Teen die helfte van 1941 is toestemming verleen vir Kleurlinge om aan te sluit by die SDF. Teen die einde van die oorlog het die SDF 837 Kleurlinge in diens gehad.

Toe die toestande in die Middellandse See in 1940 vir die Geallieerdes versleg, is die 22-Duikbootjagflottielje op spesiale versoek van Brittanje saamgestel onder bevel van luitenantkommandeur Anthony F. Trew en het in Januarie 1941 in Alexandrië aangekom. Die flottielje het bestaan uit die volgende duikbootjagskepe: $H M$ SAS Southern Floe, HM SAS Southern Isles, HM SAS Southern Sea en HM SAS Southern Maid.

Die eerste taak van hierdie skepies was om die bedreigde vaarroete na Libië te beskerm. Maar hier was die grootste bedreiging nie van die kant van vyandelike skepe nie, maar van vyandelike vliegtuie. Dus was die Suid-Afrikaners meer in 'n lugafweer rol aangewend as 'n duikbootjag-flottielje. Op 20 Januarie 1941 word die Southern Maid en Southern Isles beveel om 'n troepeskip te vergesel na Sollum. Hier het hulle voortgegaan met duikbootjagpatrollies tot 23 Januarie, toe die Southern Maid bevel gegee is om die senior vlootoffisier (binnelandse eskader) na Tobruk te neem. Tobruk is die vorige dag verower deur die Geallieerdes en op 24 Januarie was die Southern Maid die eerste Geallieerde skip wat Tobruk binnegevaar het. In die hawe het die Southern Maid haar lugafweer bewapening verbeter deur gebuite Italiaanse outomatiese wapens en ammunisie aan boord te neem. Sy het ook voldoende gebuite wapens geneem vir die Southern Isles wat op 29 Januarie by haar aangesluit het.

Die lugafweergeskut is byna onmiddellik benodig, want op 31 Januarie het altwee skepe onder 'n Duitse lugaanval deurgeloop. Daar was egter geringe skade.

Terwyl duikbote nie 'n groot las was nie, was myne tog 'n bedreiging. Op 11 Februarie het Southern Sea na haar lêplek gevaar om Southern Floe af te los, maar het geen teken van haar susterskip gesien nie. Sy was gekelder deur 'n Duitse myn en die enigste oorlewende was Stoker C.J. Jones.

In terme van die oorspronklike ooreenkoms sou die Suid-Afrikaanse skepe teen die einde Mei 
1941 teruggekeer het Suid-Afrika toe, maar die situasie in Tobruk was krities en die verliese op die sogenaamde 'Tobruk run' swaar. Die ooreenkoms is verleng en die Southern Floe is vervang deur HM SAS Protea, 'n moderne walvisjagter wat met die oog op duikbootbestryding omgebou was.

In Julie 1941 het die volgende mynveërs na die Midde-Ooste vertrek: HM SAS Treern (It H.H. Cook), HM SAS Imhoff (It H.H. Biermann), HM SAS Gribb (It A.H. Todden) en HM SAS Seksem (It J. Fairbairn). In Desember van dieselfde jaar het HM SAS Boksburgen, HM SAS Bever gevolg, terwyl in 1942 HM SAS Langlaate en HM SAS Parktown aan hierdie vaartuie toegevoeg is.

Uniek is die prestasies van HM SAS Gamtoos, 'n bergingskip van 797 ton wat op 20 Desember 1942 uit Durban in Port Said aangekom het onder meer, met luitenant-kommandeur H.H. Biermann as gesagvoerder, in September 1944 die Franse hawe Marseille binnegevaar en verskillende wrakke opgeruim het. Die OBE is in verband met hierdie werksaamhede aan It-kdr Biermann oorhandig.

Op 1 Augustus 1942 is die SDF en die RNVR (SA) geamalgameer en kom die Suid-Afrikaanse Seemag (South African Naval Forces - SANF) tot stand. Teen Oktober 1942 het die Duitse duikbote met 'n volskaalse aanslag teen skepe in die waters van Suid-Afrika begin. Gevolglik is 'n konvooistelsel nou ook tussen Durban en Kaapstad ingestel. Duikbote sou 'n hoë tol eis van Geallieerde vragskepe binne 1000 seemyl $(1852 \mathrm{~km})$ vanaf Suid-Afrika se kuste. Nie minder nie as 133 vragskepe is binne dié gebied deur duikbote gesink en ses beskadig, bo en behalwe 20 wat deur kaperskepe gekelder is. Een oorlogskip is ook deur ' $n$ duikboot gesink. Terselfdertyd is slegs drie vyandelike duikbote binne genoemde gebied gekelder

Op 9 Oktober 1943 is die Women's Auxiliary Naval Service (bekend as SWANS) tot stand gebring. Hulle sou voortaan onder andere klerklike werk doen en het die SANF in staat gestel om baie meer mans ter see aan te wend. Inderdaad was dit ' $n$ SWAN wat die eerste beheerde mynveld afgesit het in Junie 1944 gedurende ongeïdentifiseerde kruising van Saldanhabaai.

Op 31 Julie 1944 is aangekondig dat die Britse Admiraliteit drie nuwe Loch-klas fregatte aan die SANF sou skenk uit erkentlikheid vir die diens wat tot op daardie stadium gelewer is. Die eerste van hierdie fregatte - die eerste noemenswaardige oorlogskip wat ooit deur Suid-Afrika in ontvangs geneem is - was die HM SAS Good Hope wat in November 1944 in diens gestel is. Daarna het ook nog die Transvaal en Natal gevolg. Laasgenoemde het geskiedenis gemaak deur op 14 Maart 1945 die eerste skip te word om, terwyl dit nog op sy proefvaart was, 'n duikboot (U714) te kelder.

Op 1 Desember 1946 volg kdr F.J. Dean, CBE, kdr J. Dalgleish op as hoof van die SANF.

Toe die Tweede Wêreldoorlog eindig, het die SANF nie minder nie as 1436 offisiere en 8896 manskappe gehad - 'n totaal van 10332 , insluitende 837 Bruinmense en 274 dames en ook insluitende die 2944 offisiere en manskappe wat in die Britse Vloot diens gedoen het. Die SANF het slegs vyf skepe (almal gewese walvisvangers of treilers) verloor - vier in aksie terwyl een gestrand het. Die vier wat in aksie gesink het was naamlik die Southern Floe, Parktown, Bever en Treern. Die Sydostlandet het gestrand langs die Natalkus. Tydens die oorlog het 338 lede van die seemag gesterf, insluitende 35 Bruinmense.

\section{Na-oorlogsjare}

Gedurende die oorlog het die Suid-Afrikaanse regering besluit om ná die oorlog die SANF as 'n vredestydse eenheid van die Staandemag te behou. Vanselfsprekend is die eenheid voorlopig in terme van personeel en skepe verklein. Toe die SANF dus op 1 Mei 1946 as deel van die Staandemag heropgerig word, het dit uit 60 offisiere en 806 manskappe bestaan, met 17 skepe - drie fregatte, twee sperboomvaartuie, een mynlêer en elf haweverdedigingsbote. In September 1946 is die Britse Vlootvlag deur 'n SuidAfrikaanse Vlootvlag vervang.

In 1947 het die regering twee diepseemynveërs van die Britse Vloot aangekoop en word hulle in die SANF opgeneem as die Bloemfontein en Pietermaritzburg.

' $n$ Korvet is ook van die Britse Vloot aangekoop en omskep in 'n hidrografiese opmetingskip, die Protea. In 1948 is die SANF herdoop tot die "Suid-Afrikaanse Vloot". Ook is die sperboomvaartuie kort daarna tot die Fleur en Somerset herdoop en die mynlêer tot Skilpad.

Op 1 Julie 1951 word die Suid-Afrikaanse Marinierskorps gestig. Gevolglik is dit die eerste keer 
wat ' $n$ Brigadier bevelvoerder word van die Vloot, naamlik brig $P$. de Waal, $C B, C B E$, maar in 1952 word hy opgevolg deur skout-admiraal H.H. Biermann, SSA, OBE. Op 1 Oktober 1955 ontbind die Marinierskorps.

In 1952 is die prefiks 'HM SAS' met 'Suid-Afrikaanse skip/South African ship - SAS' vervang. In 1954 is die eerste van vyf seeweerbote (seaward defence vessels), die Gelderland in diens gestel. Hierdie was die eerste skip van die Vloot wat na die Tweede Wêreldoorlog gebou is - die ander was almal gewese Britse skepe wat uit die oorlog self dateer het. In 1955 is die kusmynveërs Kaapstad en Pretoria, asook nog 'n seeweerboot, Nautilus, in diens gestel. Teen 1955 het die Vloot 123 offisiere en 1314 manskappe gehad.

\section{Die Simonstadse Ooreenkoms}

Tafelbaai was nie altyd ' $n$ vellige hawe nie. Storms het dikwels groot skade onder die vlote aangerig. Hierdie ongunstige eienskap het die bekende goewerneur Simon van der Stel laat besluit om na ' $n$ inham, 'n baai te soek waar die skepe veilig kon anker. In November 1687 het die goewerneur ' $n$ besoek aan die Yselstein-baai gebring wat hy laat herdoop het tot Simonsbaai en laat opmeet het.

In 1795 met die eerste Britse besetting het Simonstad as ' $n$ deel van die Kaapkolonie, in Britse hande oorgegaan en in 1806 met die tweede besetting in die basis verder ontwikkel. Eers in 1895 is dit egter amptelik aan die Britse Admiraliteit as ' $n$ vlootbasis oorhandig, en in 1899 is begin met omvattende uitbreidings. In 1910 is die nuwe hawe, baaie en droogdok (saam bekend as die Selbourne dok) voltooi. As gevolg van die sluiting van die Suezkanaal het Simonstad tydens beide die Eerste en Tweede Wêreldoorlog as ' $n$ Geallieerde vlootbasis ' $n$ sleutelrol gespeel.

Op 1 September 1954 is die destydse Minister van Verdediging, adv F.C. Erasmus, na Engeland om die onderhandelinge te beklink wat reeds jare aan die gang was en daarop gemik was om Suid-Afrikaanse beheer oor die vlootbasis Simonstad te verkry. Brittanje sou, onder die nuwe bedeling, bepaalde voorregte behou.

Hierdie belangrike ooreenkoms het nie uitsluitlik oor die toekomstige beheer oor die vlootbasis gehandel nie, maar oor die verdediging van die seeroetes om Suid-Afrika.
Op 2 April 1957 het die plegtige oorname van die Suid-Afrikaanse Vloot se nuwe hoofbasis Simonstad met seremoniële prag en praal plaasgevind.

Suid-Afrika het $£ 75.000$ vir Simonstad aan Brittanje betaal, terwyl 'n kontrak in verband met 'n uitbreidingsprogram vir die Suid-Afrikaanse Vloot ook met Brittanje aangegaan is. Dié program het ingesluit die aankoop deur Suid-Afrika van ses duikbootjagfregatte, tien kusmynveërs en vier seeweerbote. Die totale koste verbonde aan die aankoop van die skepe sou sowat $£ 18$ miljoen bedra. Die ooreenkoms het verder ook onder andere bepaal dat die Britse Vloot in vredestryd sowel as in tye van oorlog van die basis en geriewe gebruik kon maak, en so ook bondgenote van Brittanje. Met verloop van tyd sou die latere Britse Arbeidersregering die ooreenkoms in ' $n$ baie groot mate skend en kom die huidige Konserwatiewe regering dit ook nie na die letter en gees na nie.

\section{Die Ultbreiding van die Vloot}

In Februarie 1957 kom die fregat SAS Vrystaat in Kaapstad aan. In 1958 het die mynveërs Durban, Port Elizabeth en East London gevolg, terwyl die seeweerboot Reijger ook in dieselfde jaar in diens geneem is. In 1959 het die mynveërs Johannesburg en Kimberley, die seeweerboot Haerlem, die mynveërs Mosselbaai en Walvisbaai met die seeweerboot Oosterland gevolg.

Op 28 Maart 1963 het die fregat SAS President Kruger in Simonstad aangekom. Daarna het SAS President Steyn en SAS President Pretorius, al drie nuwe tipe 12-fregatte, gevolg. Hierdie drie fregatte is spesifiek vir Suid-Afrika gebou. ' $n$ Belangrike aanwins was die aanvullingstenksip SAS Tafelberg in 1969. In dieselfde jaar is daar met die bou van die nuwe duikbootbasiskompleks by Simonstad begin en aan die einde van September 1971 is die basis, SAS Drommedaris, geopen.

Op 1 November 1969 is die Lugmag se maritieme basis en reddigsvaartuie te Langebaan na die Vloot oorgeplaas, en word herdoop tot die seereddingsbasis SAS Flamingo. In Junie 1972 het die Vloot se nuwe hidrografiese opmetingskip, die Protea, in Suid-Afrika aangekom. In Brittanje gebou en soortgelyk aan die Britse Hecla-klas, het dit die Natal vervang. Aangesien dit nie 'n oorlogskip in die operasionele sin van die woord is nie, het Brittanje die bou van die 
skip toegelaat. In Maart 1973 is die Vloot se ondergrondse hoofkwartier te Silvermine in die Kaapse Skiereiland geopen.

Op 13 Mei 1971 het Suid-Afrika se eerste duikboot, SAS Maria van Riebeeck, in Simonstad aangekom. Die susterduikbote SAS Emily Hobhouse en SAS Johanna van der Merwe het onderskeidelik in 1971 en 1972 in Simonstad aangekom.

Salisbury-eiland is in 1972 weer as ' $n$ vlootbasis heropen en kort daarna is begin om Indiërs vir diens in die Vloot op te lei. Hierdie opleidingsinrigting staan tans bekend as SAS Jalsena.

In 1972 word skout-admiraal Biermann opgevolg deur vise-adm J.J. Johnson, SM, DSC, as hoof van die vloot

Aan die begin van 1972 is aangekondig dat met Europese firmas onderhandel is vir die ontwerp en bou van ses korvette vir Suid-Afrika, moontlik onder andere met missiele bewapen. Hiervan het egter niks gekom nie. Daarna is besluit om liewer kleiner en relatief goedkoper dog hoogs gesofistikeerde vinnige missieldraende patrolliebote of aanvalsvaartuie (Engels - 'strike craft' of 'fast patrol boats' - FPB's) te bou. Die gevolg was dat die Vloot ses Minister-klas vinnige missieldraende patrolliebote bekom het, naamlik die SAS Jan Smuts, SAS P.W. Botha, SAS Frederic Creswell, SAS Jim Fouché, SAS Frans Erasmus en die SAS Oswald Pirow.

In 1977 verskuif die Vloot Hoofkwartier vanaf Simonstad na Pretoria. Hierdie verskuiwing het koördinasie en kommunikasieprobleme tussen Vloot HK en ander weermagsdele grootliks opgelos.

Ondertussen is ook ' $n$ kontrak met Frankryk gesluit vir die bou van twee Agosta-klas duikbote vir Suid-Afrika. Aan die einde van 1977 het die VVO Veiligheidsraad agter ' $n$ verpligte wapenboikot teen Suid-Afrika ingestel, en is die aflewering van hierdie vaartuie gekanselleer.

Vise-adm J. Johnson word op 1 Okt 1977 opgevolg deur vise-adm J.C. Walters, SD, as hoof van die Vloot en op 22 Jan 1980 volg vise-adm R.A. Edwards, SSAS, SM, weer op sy beurt vir viseadmiraal J.C. Walters op.
In 1979 is die Marinerskorps gestig. Hulle pligte is hawebeskerming en doen ook grensdiens.

In 1981 meld vise-adm Edwards dat die Vloot begin het met 'n ondersoek na die bou van korvette. Die noodsaaklikheid van hierdie korvette is op 'n tragiese wyse beklemtoon in die vroeë oggend van 18 Februarie 1982 toe SAS President Kruger gesink het na 'n botsing met $S A S$ Tafelberg tydens vlootoefeninge.

Waar Suid-Afrika hom vroeër sonder voorbehoud aan die kant van die Weste geskaar het en - selfs nadat die meeste Westerse lande SuidAfrika openlik op internasionale verhoë begin diskrediteer het - dit steeds op hom geneem het om die Kaapse seeroete te beskerm, ook in belang van die ondankbare Weste, is die uitgangspunt vandag dat, aangesien die Weste ons nie langer wil help nie, ons ook nie langer hulle kastaiings uit die vuur gaan krap nie.

Die Suid-Afrikaanse Vloot het ' $n$ trotse verlede en werk onverpoosd daaraan om ' $n$ hoogs moderne en slagvaardige Vlootmag op te bou.

* O/Lt J.D. Bredenkamp BA, is verbonde aan die militêre Informasieburo van die SAW

\section{Voetnotas}

1. Die totstandkoming van die Suid-Afrikaanse Afdeling van die "Royal Naval Volunteer Reserve", Militaria3/1: 7. 1971.

2 Wessels, A., "Die Suid-Afrikaanse Vloot: Verlede, Hede, Toekoms", Deel 1, Militaria 11/3: 10, 1981

.3 Ploeger, J., (dr) kol., "Ons Vloot", Paratus: 15, Mei 1973.

4. Ploeger, J., (dr) kol., op cit, 15-16.

5. Wessels, A., op cit.

6. Ibid.

7. Ploeger, J., (dr) kol., op cit, 16.

8. Wessels, A., op cit, 10-11.

9. Ploeger, J., (dr) kol., op cit, 16.

10. Ibid., D 18.

11. Wessels, A., op cit, 11

12. Ibid.

13. Ibid.

14. Ibid., 11-12.

15. Ibid., 12

16. Ibid.

17. Ploeger, J., (dr) kol., op cit, 12

18. Wessels, A., op cit, 12

19. Ploeger, J., (dr) kol., op cit, 20

20. Wessels, A., op cit, 13.

21. Ploeger, J., (dr) kol., op cit, 20-27.

22. Wessels, A., op cit, 14-16

23. Ibid., 16 .

\section{Bibliografic}

Ploeger, J., (dr) kol, Die totstandkoming van die Suid-Afrikaanse Afdeling van die "Royal Naval Volunteer Reserve", Militaria 3/1 1971.

Ploeger, J., (dr) kol, "Ons Vloot" Paratus, Mei 1973.

Wessels, A., "Die Suid-Afrikaanse Vloot: Verlede, Hede, Toekoms" deel 1 Militaria 11/13, 1981. 